\title{
VALORIZATION OF BRICK WASTES IN THE FABRICATION OF CONCRETE BLOCKS
}

\author{
OCENA ODPADKOV IZ OPEKE PRI PROIZVODNJI BETONSKIH \\ ZIDAKOV
}

\author{
Youcef Ghernouti $^{1}$, Bahia Rabehi ${ }^{1}$, Tayeb Bouziani ${ }^{2}$, Rabah Chaid ${ }^{1}$ \\ ${ }^{1}$ University M'Hamed Bougara of Boumerdes, Research Unit of Materials, Processes and Environment, Boumerdes, Algeria \\ ${ }^{2}$ University Amar Telidji of Laghouat, Structures Rehabilitation and Materials Laboratory (SREML), Algeria \\ y_ghernouti@yahoo.fr \\ Prejem rokopisa - received: 2015-07-05; sprejem za objavo - accepted for publication: 2015-10-30
}

doi:10.17222/mit.2015.202

\begin{abstract}
This work focuses on the reuse of recycled brick waste (RBW) as aggregates in the fabrication of concrete blocks. The experimental study was focused on six different concrete compositions with a $w / c$ ratio of 0.56 , a relatively constant compactness and a slump value of zero. The six compositions consist on a control concrete with natural sand and five compositions with $10 \%$, $20 \%, 30 \%, 40 \%$ and $50 \%$ of RBW as a partial substitute for the natural sand. The physical and mechanical properties of concrete blocks were studied, analyzed and compared. The obtained results showed that it is possible to manufacture concrete blocks based on RBW, and that the compressive strengths of these concrete blocks are comparable to that of the control concrete, but with an appreciable reduction in weight. The blocks made with $30 \%$ of RBW showed an improvement in the compressive strength of $42 \%$ and a reduction in weight of $11 \%$ compared to the control concretes.

Keywords: recycled brick waste, concrete block, compactness, slump, mechanical strength

Delo je usmerjeno v ponovno uporabo recikliranih odpadkov opeke (RBW) kot sestavina pri izdelavi betonskih zidakov. Eksperimentalno delo je bilo usmerjeno v šest različnih sestav betona z razmerjem $w / c$ je 0,56 , $\mathrm{z}$ relativno enako kompaktnostjo in brez zmanjšanja vrednosti. Šest sestav je predstavljalo kontrolni beton z naravnim peskom in pet sestav z dodatkom $10 \%$, $20 \%, 30 \%, 40 \%$ in $50 \%$ RBW, kot delnim nadomestkom za naravni pesek. Proučevane, analizirane in primerjane so fizikalne in mehanske lastnosti cementnih zidakov. Dobljeni rezultati so pokazali, da je mogoča izdelava cementnih zidakov na osnovi RBW. Tlačne trdnosti teh betonskih zidakov so primerljive s tistimi iz kontrolnega betona, občutno pa je zmanjšanje teže. Zidaki izdelani z $30 \%$ RBW so pokazali izboljšanje tlačne trdnosti za $42 \%$ in zmanjšanje teže za $11 \%$, v primerjavi z zidaki iz kontrolnega betona.

Ključne besede: reciklirani odpadki iz opeke, betonski zidak, kompaktnost, padec vrednosti, mehanska trdnost
\end{abstract}

\section{INTRODUCTION}

In the past decade, Algeria has been experiencing rapid development in the construction sector. Indeed, several construction projects supported by the state have been launched. The concrete block occupied an important place in this sector; this is mainly due to the simplicities related to its prefabrication and the handling facilities on site. Like any conventional concrete, concrete block consists mostly of gravel, sand, cement and water. The concrete used for the precast blocks is characterized by a rather dry state in the fresh state (needed to confer an immediate unmolding of the block) and a delicate physico-mechanical behavior in the hardened state. The difference between this type of concrete and the conventional concrete lies mainly in the low cement and water content; that is to say a high dosage of aggregate.

In the context of the judicious use of aggregates and the development of a strategy for the sustainable development policy in the building and construction sector, the use of local resources and recycled waste, such as brick waste, is required. Indeed, the introduction of recycled brick waste (RBW) in the construction industry was the subject of several research works in recent years. Thus, the use of RBW as alternative aggregates has a particular interest as it can considerably reduce the problem of waste storage and, on the other hand, can help in the preservation of natural aggregates. ${ }^{1}$

The use of clay brick as aggregates in concrete was proposed in the 1990s. ${ }^{2}$ Only a few researchers have studied the potential of using clay brick powder as a partial cement replacement to make mortar. G. Moriconi et. al. ${ }^{3}$ and L. Turanli et al. ${ }^{4}$ found that RBW, as a pozzolanic material, had the potential to suppress expansion due to the alkali-silica reaction. The possibility of using RBW as a replacement for cement has been investigated in the study of Naceri et al. ${ }^{5}$ The authors found that the mechanical behavior (compressive and flexural strengths) at $7 \mathrm{~d}$ and $28 \mathrm{~d}$ of hardened mortar decreased with an increasing RBW content. However, at $90 \mathrm{~d}$ the mortars containing up to $10 \%$ of the waste brick will reach a resistance comparable to those of mortars without RBW.

S. Wild et al. ${ }^{6}$ and M. O'Farrell et al. ${ }^{7}$ reported that the presence of RBW influenced the compressive strength and the pore size distribution of mortar. 
Table 1: Chemical and mineralogical compositions of the cement

Tabela 1: Kemijska in mineraloška sestava cementa

\begin{tabular}{|c|c|c|c|c|c|c|c|c|c|c|c|c|}
\hline \multicolumn{10}{|c|}{ Chemical composition (\%) } & \multicolumn{4}{c|}{ Mineralogical composition (\%) } \\
\hline $\mathrm{CaO}$ & $\mathrm{SiO}_{2}$ & $\mathrm{Al}_{2} \mathrm{O}_{3}$ & $\mathrm{Fe}_{2} \mathrm{O}_{3}$ & $\mathrm{MgO}$ & $\mathrm{SO}_{3}$ & $\mathrm{LOI}$ & $\mathrm{Na}_{2} \mathrm{O}$ & $\mathrm{K}_{2} \mathrm{O}$ & $\mathrm{C}_{3} \mathrm{~S}$ & $\mathrm{C}_{2} \mathrm{~S}$ & $\mathrm{C}_{3} \mathrm{~A}$ & $\mathrm{C}_{4} \mathrm{AF}$ \\
\hline 62.2 & 19.4 & 5.4 & 2.8 & 1.7 & 2.5 & 4.6 & 0.35 & 0.76 & 60 & 21 & 8 & 11 \\
\hline
\end{tabular}

Recently, some researchers have studied the possibility of using RBW as aggregate to make high-strength concrete..$^{8-14}$

P. B. Cachim ${ }^{15}$ reported that crushed bricks could be used as a partial replacement for natural coarse aggregate without a reduction in concrete properties for a $15 \%$ replacement ratio; however, a reduction up to $20 \%$ has been noted for a $30 \%$ replacement ratio.

A. K. Padmini et al. ${ }^{16}$ reported that for a given strength, the modulus of elasticity of concrete made with crushed brick is between one-half and two-thirds that of normal concrete. Moreover, the water absorption and sorptivity increased for the concrete containing crushedbrick aggregates. Furthermore, concrete containing coarse crushed bricks aggregate had a relatively lower strength during the early ages than normal aggregate concrete. This is due to the higher water absorption of crushed brick aggregates compared to natural aggregates. $^{17}$

A. R. Khaloo ${ }^{18}$ found a decrease of $7 \%$ in the concrete's compressive strength by using crushed clinker bricks as the coarse aggregate compared to natural aggregate.

A. A. Akhtaruzzaman and A. Hasnat ${ }^{19}$ found that the tensile strength of concrete containing coarse crushed brick was higher than that of normal concrete by about $11 \%$. T. Kibriya and P. R. S. Speare ${ }^{20}$ reported that concrete containing coarse, crushed brick had comparable compressive, tensile and flexural strengths to those of normal concrete, but the modulus of elasticity was drastically reduced.

C. S. Poon and D. S. Chan ${ }^{21}$ found that the incorporation of $20 \%$ of fine crushed brick aggregate decreased the compressive strength and the modulus of elasticity of the concrete by $18 \%$ and $13 \%$, respectively.

The present experimental investigation constitutes a continuation of the work and aims to expand the use of this material in the prefabrication of concrete blocks. In this work, an optimizing of concrete block mixtures, based on natural sand and different percentages of RBW, was performed. Next, the influence of RBW on the physico-mechanical properties of the produced concrete blocks was tested.

\section{EXPERIMENTAL PART}

\subsection{Materials}

The concrete block mixtures investigated in this study were prepared with Ordinary Portland Cement (OPC) CEM II/A 42.5. The mineralogical and chemical compositions of the cement are listed in Table 1. The aggregates used are natural sand (NS), with a maximum particle size of $2 \mathrm{~mm}$ and a siliceous mineralogical nature. A crushed limestone gravel with a particle size between $3 \mathrm{~mm}$ and $8 \mathrm{~mm}$ and a recycled brick waste (RBW) aggregate resulting from crushing of the rejected bricks, composed mainly from the quartz and with a maximum particle size of $2 \mathrm{~mm}$. The physical properties and granular size analysis of all the aggregates used in this work are listed and presented in Table $\mathbf{2}$ and Figure $\mathbf{1}$.

Table 2: Physical properties of aggregates used

Tabela 2: Fizikalne lastnosti uporabljenih sestavin

\begin{tabular}{|l|c|c|c|}
\hline & $\begin{array}{c}\text { Natural } \\
\text { sand (NS) }\end{array}$ & $\begin{array}{c}\text { Recycled brick } \\
\text { waste (RBW) }\end{array}$ & Gravel (3/8) \\
\hline $\begin{array}{l}\text { Apparent density, } \\
\left.\text { Ad (g/cm }{ }^{3}\right)\end{array}$ & 1.49 & 0.97 & 1.35 \\
\hline $\begin{array}{l}\text { Specific gravity, } \\
\left.\text { SG (g/cm }{ }^{3}\right)\end{array}$ & 2.59 & 1.21 & 2.64 \\
\hline $\begin{array}{l}\text { Visual equivalent, } \\
\text { VES (\%) }\end{array}$ & 72 & 67 & $/$ \\
\hline $\begin{array}{l}\text { Finesse modulus, } \\
\text { Fm }\end{array}$ & 1.05 & 4.7 & $/$ \\
\hline Porosity (\%) & 26.6 & 34.9 & 33.3 \\
\hline $\begin{array}{l}\text { Water absorption } \\
(\%)\end{array}$ & 1.86 & 7.4 & 1.4 \\
\hline
\end{tabular}

\subsection{Formulation of concrete blocks}

In the mix design of this type of concrete, the compactness criterion and maneuverability have been considered for the fresh state, since the mechanical strength of this type of concrete used in the manufacture of concrete blocks is not a very important criterion. (The mechanical strengths of the blocks are relatively low compared to traditional concrete). The first step in formulating the blocks is the optimization of the aggregates dosage (natural Sand + Gravel) by choosing the most compact mixture. Then the second step is to search the

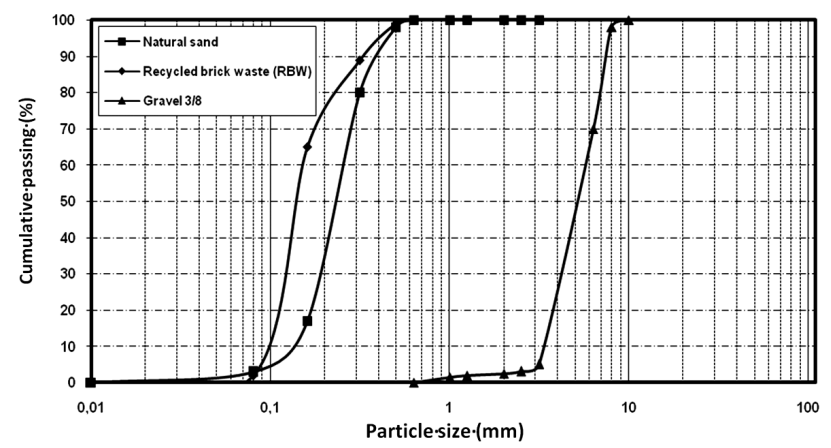

Figure 1: Granular size analysis of all aggregates

Slika 1: Analiza velikosti zrn vseh sestavin 


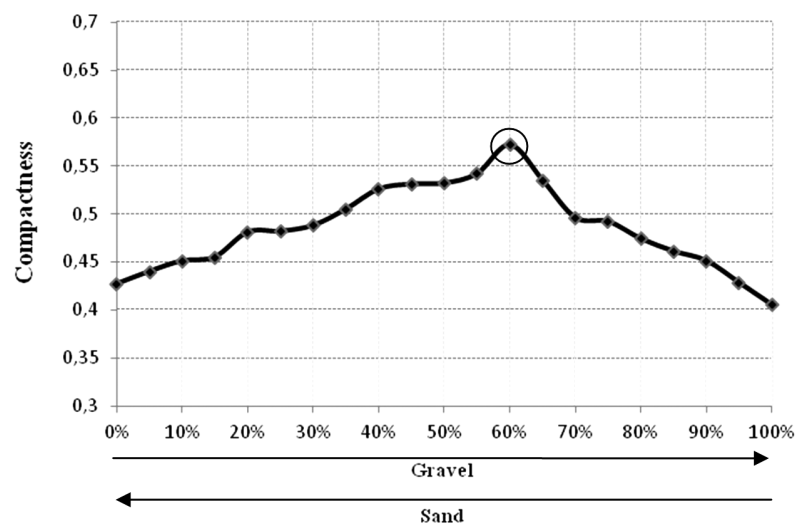

Figure 2: Compactness value depending on the percentage of sand and gravel

Slika 2: Vrednosti kompaktnosti v odvisnosti od odstotka peska in gramoza

dosage of water that verifies the criteria required for the concrete blocks (no slump and maximum compactness), while fixing the cement content ( $8 \%$ to $9 \%$ by weight of the aggregates). ${ }^{22}$ The third step is to replace some natural sand in the optimized mixture by different percentages of RBW, from $10 \%$ to $50 \%$, with an increment of $10 \%$.

\subsubsection{Optimization of aggregates dosage}

In our work, we started by optimizing the dosage of dry aggregates, using as criteria the maximum compactness of the mixture. We used a Modified Proctor test for determining the compactness of the mixtures (gravel and sand). Calculating the compactness is performed after a period of vibration of $30 \mathrm{~s}$ using a standard vibrating table. The results of the compactness of the mixture (sand + gravel) are represented in Figure 2. According to the results, the most compact mixture is that which contains $60 \%$ gravel and $40 \%$ sand (compactness $=0.572$ ).

\subsubsection{Optimization of water content}

The second step is to find the dosage of water that verifies the criteria required for concrete blocks (no

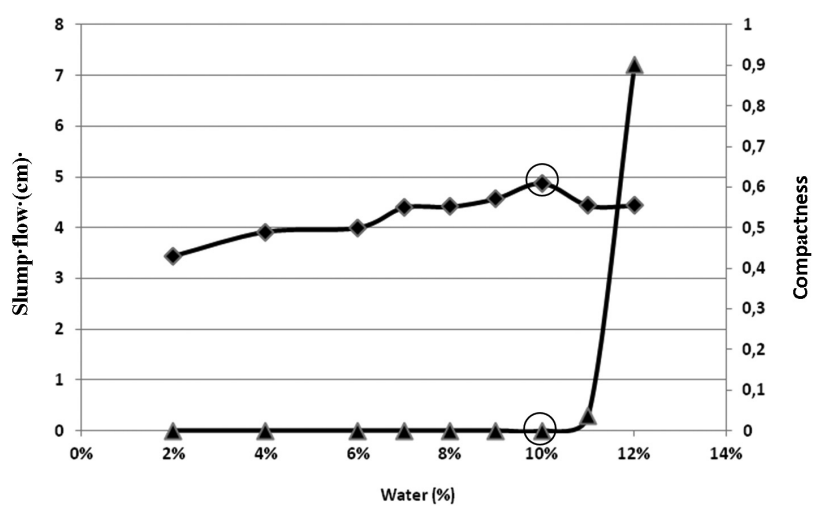

Figure 3: Compactness and slump flow values depending on the percentage of water

Slika 3: Kompaktnost in padec tekočnosti v odvisnosti od odstotka vode
Table 3: Examples of slump flow depending on the percentage (\%) of water

Tabela 3: Primer zmanjšanja tekočnosti v odvisnosti od odstotka (\%) vode

\begin{tabular}{|c|c|c|c|}
\hline$(\%)$ of water & $\begin{array}{c}\text { Images of } \\
\text { slump flow test }\end{array}$ & $(\%)$ of water & $\begin{array}{c}\text { Images of } \\
\text { slump flow test }\end{array}$ \\
\hline$(\% / \mathrm{w})=2 \%$ & & $(\% / \mathrm{w})=4 \%$ & U \\
\hline $\begin{array}{l}\text { Slump flow } \\
=0 \mathrm{~mm}\end{array}$ & & $\begin{array}{l}\text { Slump flow } \\
=0 \mathrm{~mm}\end{array}$ & \\
\hline $\begin{array}{l}\text { Compactness } \\
=0.43\end{array}$ & & $\begin{array}{l}\text { Compactness } \\
=0.49\end{array}$ & \\
\hline$(\% / w)=6 \%$ & & $(\% / w)=7 \%$ & \\
\hline Slump flow & & Slump flow & \\
\hline$=0 \mathrm{~mm}$ & & $=0 \mathrm{~mm}$ & \\
\hline $\begin{array}{l}\text { Compactness } \\
=0.5\end{array}$ & & $\begin{array}{l}\text { Compactness } \\
=0.55\end{array}$ & \\
\hline$(\% / \mathrm{w})=8 \%$ & & $(\% / \mathrm{w})=9 \%$ & \\
\hline $\begin{array}{l}\text { Slump flow } \\
=0 \mathrm{~mm}\end{array}$ & & $\begin{array}{l}\text { Slump flow } \\
=0 \mathrm{~mm}\end{array}$ & \\
\hline $\begin{array}{l}\text { Compactness } \\
=0.55\end{array}$ & & $\begin{array}{l}\text { Compactness } \\
=0.58\end{array}$ & \\
\hline $\begin{array}{l}(\% / \mathrm{w})= \\
10 \%\end{array}$ & & $\begin{array}{l}(\% / \mathrm{w})= \\
12 \%\end{array}$ & \\
\hline $\begin{array}{l}\text { Slump flow } \\
=0 \mathrm{~mm}\end{array}$ & & $\begin{array}{l}\text { Slump flow } \\
=30 \mathrm{~mm}\end{array}$ & \\
\hline $\begin{array}{l}\text { Compactness } \\
=0.61\end{array}$ & & $\begin{array}{l}\text { Compactness } \\
=0.55\end{array}$ & \\
\hline
\end{tabular}

slump and maximum compactness), while fixing the cement content (8\% to $9 \%$ of the weight of the aggregate). The water dosage ranges from $2 \%$ to $12 \%$ by weight of solid mixture (gravel, sand and cement). The slump is performed using the Abrams cone. In parallel the compactness of prepared fresh concrete was measured using a modified proctor mold.

The results of the measurements of the Slump flow and compactness depending on the percentage of water are shown in Figure 3. Corresponding pictures for each mixture are shown in Table 3. From the results obtained, the most compact mixture that checks a zero slump flow is the mixture containing $10 \%$ of water.

\subsubsection{Incorporation of $R B W$ in the optimized composition}

In this step, a portion of the natural sand from the optimized formulation was replaced by different percentages $(10 \%, 20 \%, 30 \%, 40 \%$ and $50 \%)$ of RBW aggregate.

Table 4: Formulations and dosages of the constituents in $\mathrm{kg} / \mathrm{m}^{3}$ Tabela 4: Sestava in odmerek sestavin $\mathrm{v} \mathrm{kg} / \mathrm{m}^{3}$

\begin{tabular}{|c|c|c|c|c|c|}
\hline $\begin{array}{c}\text { Formu- } \\
\text { lation }\end{array}$ & Cement & Gravel & Water & $\begin{array}{c}\text { Natural } \\
\text { sand } \\
\text { (NS) }\end{array}$ & $\begin{array}{c}\text { Recycled } \\
\text { brick } \\
\text { waste } \\
\text { (RBW) }\end{array}$ \\
\hline BNS & 142 & 875 & 80 & 564 & $/$ \\
\hline BBW10 & & & & 508 & 56 \\
\hline BBW20 & & & & 452 & 113 \\
\hline BBW30 & & & & 339 & 170 \\
\hline BBW40 & & & 508 & 226 \\
\hline BBW50 & & & & & 282 \\
\hline
\end{tabular}


Table 4 gives the dosages of the constituents in the mixture for the optimized formulation of the block concrete based on natural sand and block concrete based on RBW aggregate.

\subsubsection{Optimization of slump flow and compactness}

For each composition, the conditions for obtaining concrete blocks for a slump value of 0 are respected. The obtained results are shown in Table 5.

Table 5: Examples of slump flow for all formulations Tabela 5: Primeri zmanjšanja tekočnosti vseh sestav

\begin{tabular}{|c|c|c|c|}
\hline Composition & Slump flow test & Composition & Slump flow test \\
\hline BNS & & BBW10 & \\
\hline Slump flow $=$ & & Slump flow $=$ & \\
\hline Compactness & & Compactness & \\
\hline & & $=0.52$ & \\
\hline BBW20 & & BBW30 & \\
\hline Slump flow $=$ & & Slump flow $=$ & \\
\hline $0 \mathrm{~mm}$ & & $0 \mathrm{~mm}$ & \\
\hline Compactness & & Compactness & \\
\hline BBW40 & & BBW50 & \\
\hline Slump flow $=$ & & Slump flow $=$ & \\
\hline $0 \mathrm{~mm}$ & & $0 \mathrm{~mm}$ & \\
\hline Compactness & & Compactness & \\
\hline$=0.49$ & -1 & $=0.42$ & \\
\hline
\end{tabular}

\subsubsection{Preparation of concrete blocks}

Our study was performed on hollow blocks with dimensions of $(10 \times 20 \times 40) \mathrm{cm}$. The mixing is performed on site with a concrete mixer. The mixed concrete is then loaded into the laying machine. Excess concrete is leveled using a striking surface so that the blocks can have a rough surface. The blocks are removed from the molds immediately and thoroughly on a concrete platform (Figure 4). The blocks are kept on site for $24 \mathrm{~h}$, and then they are transported to the laboratory and are watered every day for $28 \mathrm{~d}$.

\subsection{Characterization of concrete blocks}

\subsubsection{Dimensional variation}

The tests of dimensional variation were conducted on specimens of $(4 \times 4 \times 16) \mathrm{cm}$ with the same concrete made for the realized concrete blocks. For each formulation, four specimens were crafted. Two are left in the open air to measure the shrinkage and two are immersed in the water to measure the swelling.

\subsubsection{Porosity and water absorption}

The measurements of porosity and water absorption are performed according to the NF P18 554 standards, on block samples previously realized. The porosity is the amount of water absorbed using a dry sample mass. It is determined using the following Equation (1):

$$
P=\left[\left(M_{\mathrm{a}}-M_{\mathrm{S}}\right) /\left(M_{\mathrm{a}}-M_{\grave{a}}\right)\right] \times 100
$$

where:

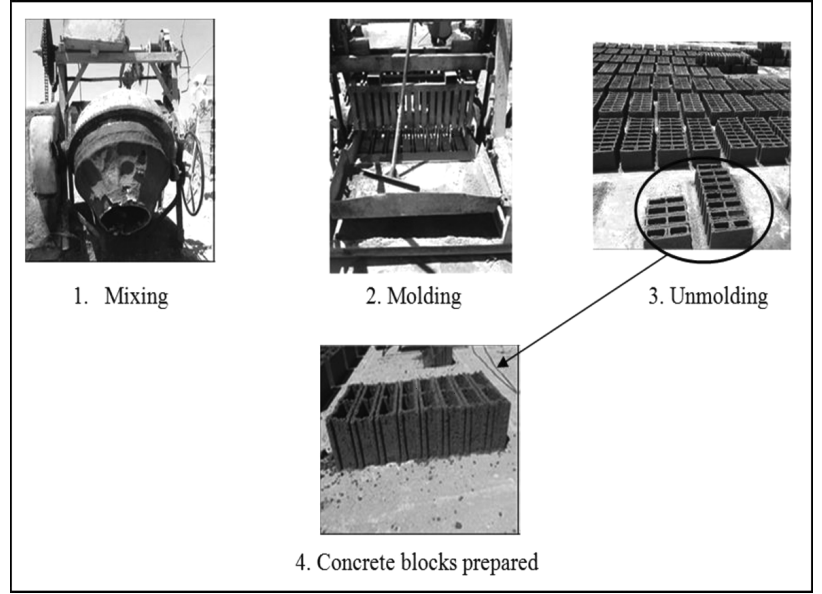

Figure 4: Fabrication of blocks

Slika 4: Izdelava zidakov

$M_{\mathrm{a}}$ : weight of sample at a dry surface.

$M$ s: weight of the sample after drying.

$M_{\mathrm{a}}$ : weight of the sample after immersion in water for $24 \mathrm{~h}$.

\subsubsection{Compressive strength}

After surfacing of the lower and upper bearing faces of each block with sulfur, the compression test is performed by applying a continuous load without shock at a constant speed of $0.5 \mathrm{MPa} / \mathrm{s}$. The test machine is a press for hard materials according to NFP 18-412; it is calibrated in terms of these standards (Figure 5). The compressive strength $R_{\mathrm{c}}$ is obtained using the following Equation (2):

$$
R_{\mathrm{C}}=\left[C /\left(S_{\mathrm{b}} \times 10\right)\right] \times\left(S_{\mathrm{a}} / S_{\mathrm{n}}\right)
$$

where:

$C$ : breaking load of the block,

$S_{\mathrm{b}}$ (Gross Section): Area obtained by multiplying both dimensions, thickness and length, measured in the same horizontal section,

$S_{\mathrm{n}}$ (Net Section): Area in a horizontal section concrete, empty deducted,

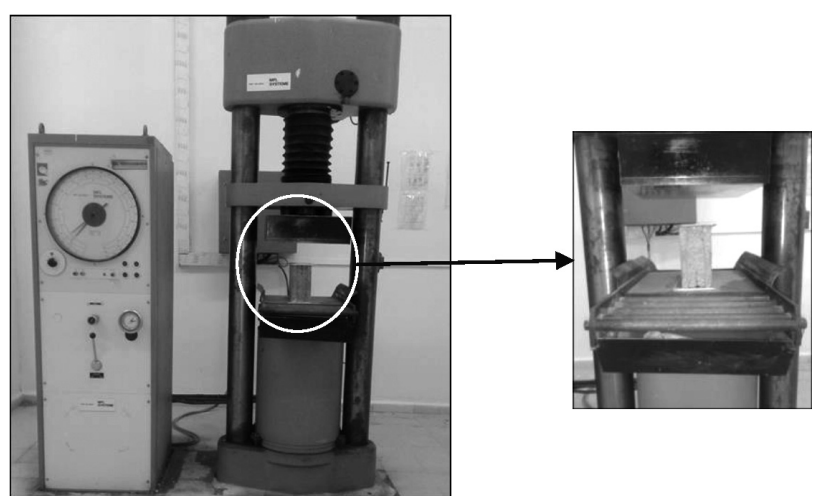

Figure 5: Compressive strength test Slika 5: Preizkus tlačne trdnosti 
$S_{\mathrm{a}}$ (Support Section): Common area of contact face and supporting face.

\section{RESULTS AND DISCUSSION}

\subsection{Dimensional variation of the concrete blocks}

The results of shrinkage and swelling are shown in Figure 6. The obtained results show that for all compositions of concrete blocks, the shrinkage increases rapidly until the age of $14 \mathrm{~d}$, ranges from $9.43 \mathrm{~mm} / \mathrm{m}$ to $10.54 \mathrm{~mm} / \mathrm{m}$, which may result in a loss of weight due to the phenomenon of setting and hardening of concrete in the early days of hydration, subsequently a dimensional stability is recorded until $28 \mathrm{~d}$. The values of the shrinkage for all compositions based on RBW are lower than the composition based on natural sand; this may be due to the improvement of compactness by the incorporation of RBW. All the specimens show a considerable swelling until the age of $14 \mathrm{~d}$, ranges from $13.54 \mathrm{~mm} / \mathrm{m}$ to 15.58 $\mathrm{mm} / \mathrm{m}$, due to water absorption by the concrete blocks, subsequently a dimensional stability is recorded until 28 $\mathrm{d}$; this is may be due to the saturation of the pores and capillaries. The swelling of the BBW40 and BBW50 specimens was not studied because it deteriorated immediately after the immersion in water. Finally, the obtained results show that the replacement of sand by RBW until $30 \%$ does not have a significant effect on the evolution of the shrinkage and the swelling of the concrete blocks. The maximum difference is in the order of $11 \%$ in the case of shrinkage and $9 \%$ in the case of swelling.

\subsection{Porosity and water absorption of concrete blocks}

The evolution of porosity and water absorption are shown in Figure 7. These results show that the water absorption of all the blocks varies in the same manner as

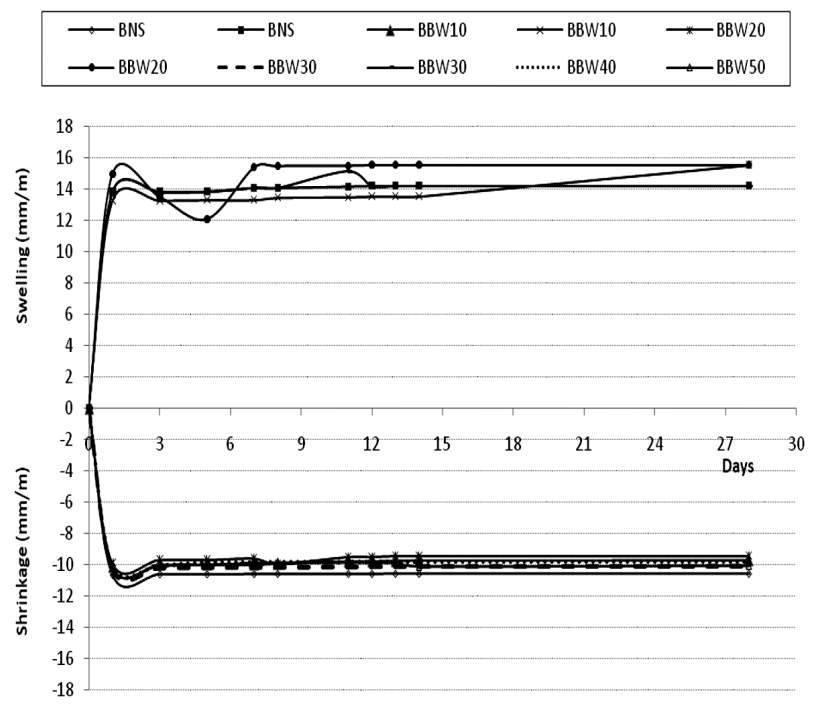

Figure 6: Shrinkage and swelling of concrete blocks Slika 6: Krčenje in nabrekanje betonskih zidakov

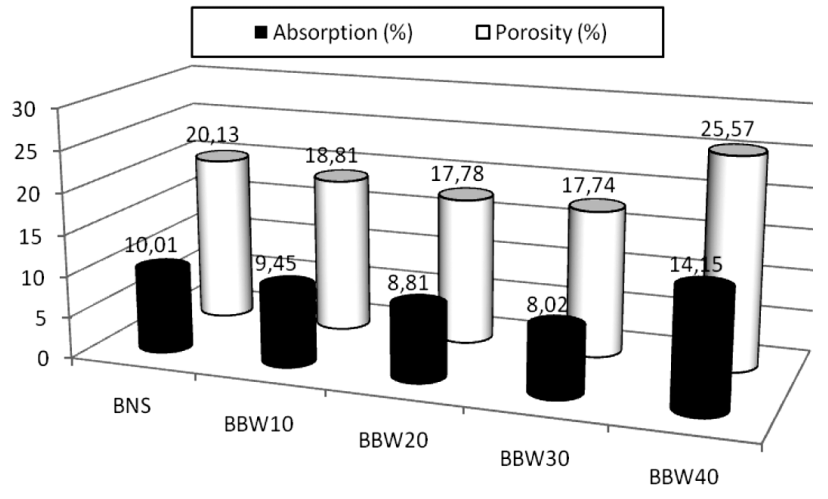

Figure 7: Porosity and water absorption of concrete blocks Slika 7: Poroznost in absorpcija vode v betonskih blokih

the porosity. The porosity decreases with the replacement content of sand by the RBW aggregate. However, up to a $40 \%$ of replacement, an increase of the porosity is recorded. The decrease of the porosity and water absorption at a less than $40 \%$ replacement of sand by RBW aggregate, can be explained by the form of the RBW aggregate (angular form), the RBW makes it possible to improve the compactness of mixture, the contact is perfect and distribution of waste brick grains, is uniform. Indeed, it fills the voids among the grains of sand. The mixtures containing less than $40 \%$ of RBW waste aggregates having a gravel $3 / 8$ with two sands (natural and recycled) having a size more or less identical with the presence of some fine material for the recycled aggregate, which allows for a more compact granular skeleton. The composition with $30 \% \mathrm{RBW}$ has a porosity of $11 \%$ less than the composition with natural sand. The increased porosity and water absorption beyond $40 \%$ replacement can be explained by the large amount of RBW aggregate in the mixture; it is a porous material in comparison to the natural sand, which is a less porous material.

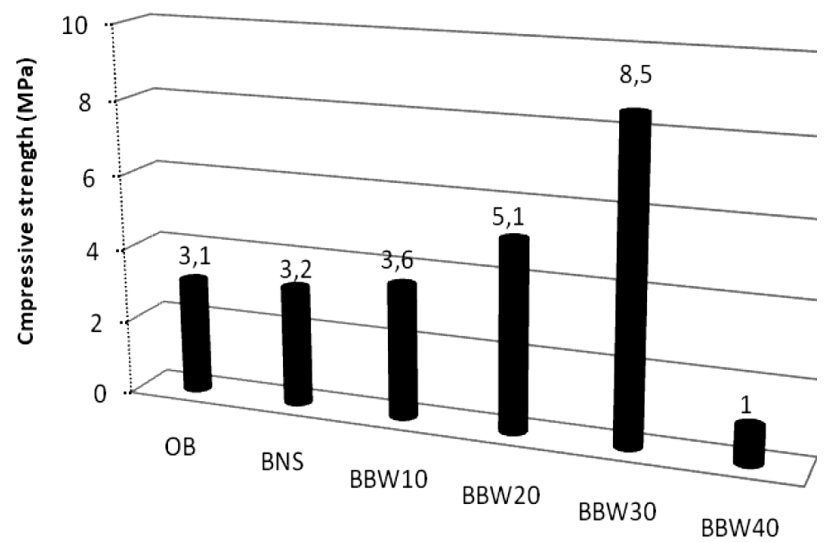

Figure 8: Compressive strength of concrete blocks in comparison with ordinary concrete blocks

Slika 8: Tlačna trdnost cementnih zidakov v primerjavi z običajnimi cementnimi zidaki 


\subsection{Compressive strength of concrete blocks}

The results of the compressive test on all the concrete blocks are shown in Figure 8. The blocks with RBW aggregate have a greater compressive strength than the blocks with natural sand, the concrete blocks containing $30 \%$ of RBW have a gain of about $43 \%$ compared to the concrete blocks with natural sand in compressive strength, which can be explained by the high compactness of this composition based on RBW, while the absorption and porosity decrease in parallel. The compressive strength of the BBW40 concrete blocks decreases; this may be due to the decrease in compactness. The compressive strengths of all the realized blocks (BNS, BBW10, BBW20 and BBW30) are better than those of the usual blocks realized in the block prefabrication site (ordinary concrete blocks: OCB).

\section{CONCLUSION}

This study presents the use of recycled brick waste (RBW) as sand in concrete blocks. On the basis of the obtained results, the following conclusions can be drawn:

- It is possible to use RBW as a fine aggregate for the manufacturing of concrete blocks. The shrinkage and swelling of these blocks decreases according to the increase of compactness.

- All the studied concrete blocks have the same density regardless of the replacement rate of natural sand by RBW.

- The replacement of $30 \%$ natural sand by the RBW enabled us to achieve concrete blocks with better characteristics: a maximum compactness, an acceptable shrinkage and swelling (similar to that of concrete with natural sand), a low porosity and water absorption in comparison with other compositions, a weight reduction of $11 \%$ and a higher compressive strength than the concrete blocks with natural sand (a gain of $43 \%$ ).

Finally, we can conclude that the RBW can be used as a fine aggregate to produce concrete blocks, which allows us to reduce the waste inventory levels in brick and limit the deficit aggregates in some areas.

\section{REFERENCES}

${ }^{1}$ F. Debieb, S. Kenai, The use of coarse and fine crushed bricks as aggregate in concrete, Constr. Build. Mater., 22 (2008) 5, 886-93, doi:10.1016/j.conbuildmat.2006.12.013

${ }^{2}$ T. C. Hansen, Recycling of demolished concrete masonry, Rilem Report No. 6, E\&FN Spon, London, 1992, 316

${ }^{3}$ G. Moriconi, V. Corinaldesi, R. Antonucci, Environmentally-friendly mortars: a way to improve bond between mortar and brick, Mater Struct, 36 (2003) 10, 702-708, doi:10.1007/BF02479505

${ }^{4}$ L. Turanli, F. Bektas, P. J. M. Monteiro, Use of ground clay brick as a pozzolanic material to reduce the alkali-silica reaction, Cem. Concr. Res., 33 (2003) 10, 1539-1542, doi:10.1016/S0008-8846(03) 00101-7
${ }^{5}$ A. Naceri, H. M. C. Hamina, Use of waste brick as a partial replacement of cement in mortar, Waste Management, 29 (2009) 8, 2378-2384, doi:10.1016/j.wasman.2009.03.026

${ }^{6}$ S. Wild, J. M. Khatib, S. D. Addis, The potential of fired brick clay as a partial cement replacement material, International congress-concrete in the service of mankind, concrete for environment enhancement and products, University of Dundee, Eds. Dhir and Dyer, E\&FN SPON, (1996), 685-696

${ }^{7}$ M. O'Farrell, S. Wild, B. B. Sabir, Pore size distribution and compressive strength of waste clay brick mortar, Cem Concr Compos, 23 (2001) 1, 81-91, doi:10.1016/S0958-9465(00)00070-6

${ }^{8}$ B. Rabehi, Y. Ghernouti, K. Boumchedda, Strength and compressive behaviour of ultra high-performance fibrereinforced concrete (UHPFRC) incorporating Algerian calcined clays as pozzolanic materials and silica fume, European Journal of Environmental and Civil Engineering, 17 (2013) 8, 599-615, doi:10.1080/19648189. 2013.802998

${ }^{9}$ B. Safi, A. Aboutair, M. Saidi, Y. Ghernouti, C. Oubraham, Effect of the heat curing on strength development of ultra-high performance fiber reinforced concrete (UHPFRC) containing dune sand and ground brick waste, J. Build. Mater. Struct., 1 (2014) 1, 40-46

${ }^{10}$ M. A. Mansur, T. H. Wee, S. C. Lee, Crushed bricks as coarse aggregate for concrete, ACI Mater. J., 96 (1999) 4, 478-84

${ }^{11}$ H. L. Cheng, Study on recycled concrete made by fly-ash and waste clay-brick, China Concr. Cem. Prod., (2005) 5, 48-50

${ }^{12}$ J. M. Khatib, Properties of concrete incorporating fine recycled aggregate, Cem. Concr. Res., 35 (2005) 4, 763-769, doi:10.1016/ j.cemconres.2004.06.017

${ }^{13}$ F. M. Khalaf, Using crushed clay brick as coarse aggregate in concrete, J. Mater. Civil. Eng., 18 (2006) 4, 518-526, doi:10.1061/ (ASCE)0899-1561(2006)18:4(518)

${ }^{14}$ H. D. Yan, X. F. Chen, Experimental studies and analyses on properties of clay brick recycled aggregate concrete, Tenth nation cement and concrete chemistry and application technology conference, 2007, China

${ }^{15}$ P. B. Cachim, Mechanical properties of brick aggregate concrete, Constr. Build. Mater., 23 (2009) 3, 1292-1297, doi:10.1016/ j.conbuildmat.2008.07.023

${ }^{16}$ A. K. Padmini, K. Ramamurthy, M. S. Mathews, Relative moisture movement through recycled aggregate concrete, Mag. Concr. Res., 54 (2002) 5, 77-384, doi:10.1680/macr.2002.54.5.377

${ }^{17}$ M. Zakaria, J. G. Cabrera, Performance and durability of concrete made with demolition waste and artificial fly ash-clay aggregates, Waste Manage, 16 (1996) 1-3, 151-158, doi:10.1016/S0956053X(96)00038-4

${ }^{18}$ A. R. Khaloo, Properties of concrete using crushed clinker brick as coarse aggregate, ACI Mater. J., 91 (1994) 4, 401-407

${ }^{19}$ A. A. Akhtaruzzaman, A. Hasnat, Properties of concrete using crushed brick as aggregates, Concr. Int., 5 (1983) 2, 58-63

${ }^{20}$ T. Kibriya, P. R. S. Speare, The use of crushed brick coarse aggregate concrete, Proceedings of international conference-concrete for environment enhancement and protection, Scotland, University of Dundee, 1996

${ }^{21}$ C. S. Poon, D. Chan, The use of recycled aggregate in concrete in Hong Kong, Resour Conserv. Recycl., 50 (2007) 3, 293-305, doi:10.1016/j.resconrec.2006.06.005

${ }^{22}$ T. Bouziani, A. Ferhat, M. Bederina, Optimisation des paramètres de formulation des bétons destinés à la préfabrication des blocs de béton par une approche RNA (Réseaux de Neurones Artificiels), Revue des Sciences et Sciences de l'Ingénieur, 2 (2011), 34-41 